\title{
A Experimental Study of Air Heating Plane Solar Panels as Used in Drying Papayes
}

\author{
Abene Abderrahmane \\ University of Valenciennes, ISTV Science Faculty, Valenciennes, France
}

Email address:

a.abene@yahoo.fr

To cite this article:

Abene Abderrahmane. A Experimental Study of Air Heating Plane Solar Panels as Used in Drying Papayes. Science Journal of Energy Engineering. Vol. 3, No. 3, 2015, pp. 23-32. doi: 10.11648/j.sjee.20150303.12

\begin{abstract}
One of the major problems concerning the use of solar panels for heating is the low level of thermal interchange with air in the dynamic vein of the solar panel. This weakness in such systems does not enable an optimum performance or high level of thermal efficiency to be obtained from their use. There is, however, a very noticeable improvement to thermal transfer when baffles are placed in rows in the ducts. To conduct the experiments, solar energy was simulated, the aim being to improve the ratio between temperature and thermal efficiency of an air heating plane solar panel and to make use of the system to reduce the drying time of papayes.
\end{abstract}

Keywords: Solar Energy, Simulation, An Air Heating Plane Solar Panel, Effects of Baffles Placed in the Vein, The Ratio Between Temperature and Thermal Efficiency of the Solar Panel, Drying, Papayes

\section{Introduction}

To improve the performance of solar panels, a wise choice of their components enables thermal losses between the absorber and the environment to be limited. Recent research studies have focussed more particularly on the circulation of the coolant fluid as a means of optimising performances and in which several methods have been proposed to deal with this objective. Zugary and Vulliere [1] sought to limit the losses near the fore part of the solar panel; two other researchers [2, 3] centred their work more on the absorber the active part of the solar panel\} while yet other papers [2-8] have shown that placing baffles in the dynamic air vein of the solar panel enables a turbulent air flow to be created which in turn boosts the interchange of thermal convection between the air and the absorber.

The baffles have to be placed very carefully. They can be fixed either onto the insulating material or under the absorber or indeed in both positions. In all three cases, results are improved because of the reduction of the hydraulic diameter $\left(D_{h}\right)$ when compared with the performances of solar panels without baffles. In the air flow vein, the Reynolds number is calculated by starting from the maximum speed $\left(\mathrm{V}_{\mathrm{m}}\right)$ corresponding to the minimum air flow section of the duct $\left(\mathrm{S}_{\min }\right)$ and is expressed by :

$$
\begin{gathered}
\operatorname{Re}=\frac{\mathrm{V}_{\mathrm{m}} \mathrm{D}_{\mathrm{h}}}{v}=\frac{\mathrm{Q}_{\mathrm{v}} \cdot \mathrm{D}_{\mathrm{h}}}{v \cdot \mathrm{S}_{\min }} \text { with } \mathrm{D}_{\mathrm{h}}=\frac{2 \mathrm{~d} \ell}{\mathrm{d}+\ell} \\
\text { By } \mathrm{d}<<\ell \Rightarrow \mathrm{d}+\ell \approx \ell \text { so } \mathrm{D}_{\mathrm{h}}=2 \mathrm{~d} \\
\text { Posing } \mathrm{b}^{\prime}=1 \frac{\mathrm{S}}{\mathrm{d} \ell} \quad \text { we are } \operatorname{Re}=\frac{2 \mathrm{Q}_{\mathrm{v}}}{v \cdot \ell \cdot\left(1-\mathrm{b}^{\prime}\right)}
\end{gathered}
$$

$\mathrm{D}_{\mathrm{h}}$ : the hydraulic diameter of the duct

b': the blockage coefficient in the air vein

The coefficient of thermal convection interchange $\left(\mathrm{h}_{\mathrm{ccf}}\right)$ between the absorber and the coolant fluid is dependent on the Reynolds number; it is an increasing Re function, otherwise $h$ does not increase. It can therefore be deduced that when b' increases, both $\mathrm{Re}$, and consequently $\mathrm{h}_{\text {ccf, increase. The }}$ minimum air flow section of the duct $\left(\mathrm{S}_{\min }\right)$ is dependent on the shape of the baffles, their dimensions and their layout in relation one to another. The following three positional fixings of the baffles have been studied:

- fixed onto the insulating material: according to the shape chosen, the flow becomes turbulent and the fragmentation of swirls takes place very close to the absorber towards which the air is orientated and thermal transfer is improved

- fixed under the absorber: in addition to the aeraulic effect, these baffles also act as blades which means that 
the thermal transfer capacity emanating from the surface of the absorber increases and which in turn contributes to the improvement in the efficiency of the solar panel. As regards some of those shapes already studied [2], the results obtained have shown that with weak air flow, efficiency increases whereas with air flow stronger than a given value, efficiency tends to decrease. Where the air flow is very strong, swirls are much more evident near the insulation material. This positioning of the baffles results in a less efficient performance. Indeed, at the tips of the blades, the air temperature is lower than it is at the abosrber.

- To improve the performance of this second positioning, some intermediate baffles can be fixed onto the insulating material which will convey air flow towards the absorber [2]. In this case, charge losses in the solar panel will be higher and its thermal inertia will increase.

Given the above findings and to continue with the experiments, it was decided to fix the baffles onto the insulating material. When choosing the geometrical shape of the baffles to be used, certain criteria have to be satisfied. Indeed, both the layout and the shape of the baffles influence air flow during its trajectory. The baffles ensure that the absorber is well irrigated, reduce the zones of inertia, create turbulence and lengthen the course of the air by increasing the time it remains in the solar panel. A meticulous and systematic study was then undertaken of several different methods of arrangement of the air flow veins in the solar panels.

The first part of this paper deals with a comparison of the results obtained, initially using solar panels without baffles (SC) and then with baffles. Of the latter, two types were selected, namely Delta-shaped Curved Longitudinally (DCL1) and Ogival-shaped Curved Longitudinally (OCL1) baffles. The second part concerns the results obtained when firstly using solar panels without baffles and then with DCL1 baffles for drying papayes. In addition, to conduct experiments that would highlight the effects of baffles even further, papayes were dried by using a solar panel provided with Transversal-Longitudinal ones (TL) of the same type as those already studied [4]. A comparison of the results obtained shows that a solar panel provided with baffles is far more efficient than one without them.

\section{Experimental Device}

The solar panel with a single passage of air (Fig. 2) consists of:

- a transparent, alveolar, $1 \mathrm{~cm}$ thick polycarbonate cover. The coefficients of transmission $\left(\tau_{\mathrm{c}}\right)$ and emissivity $\left(\varepsilon_{\mathrm{c}}\right)$ are respectively $83 \%$ and $90 \%$ for different wavelengths

- an absorber made of a $0.4 \mathrm{~mm}$ thick aluminium sheet painted in mat black on the insulation side. The thermal conductivity $\left(\alpha_{\mathrm{a}}\right)$ and absorption $\left(\mathrm{K}_{\mathrm{a}}\right)$ coefficients are respectively $95 \%$ and $205 \mathrm{~W} / \mathrm{m} . \mathrm{K}$. The distance (d) on each side of the absorber is $0.025 \mathrm{~m}$.

- a $5 \mathrm{~cm}$ thick polystyrene plate of insulating material which can resist temperatures higher than $90^{\circ} \mathrm{C}$. Its coefficient of thermal conductivity $\left(\mathrm{K}_{\mathrm{is}}\right)$ is equal to 0.04 $\mathrm{W} / \mathrm{m} . \mathrm{K}$.

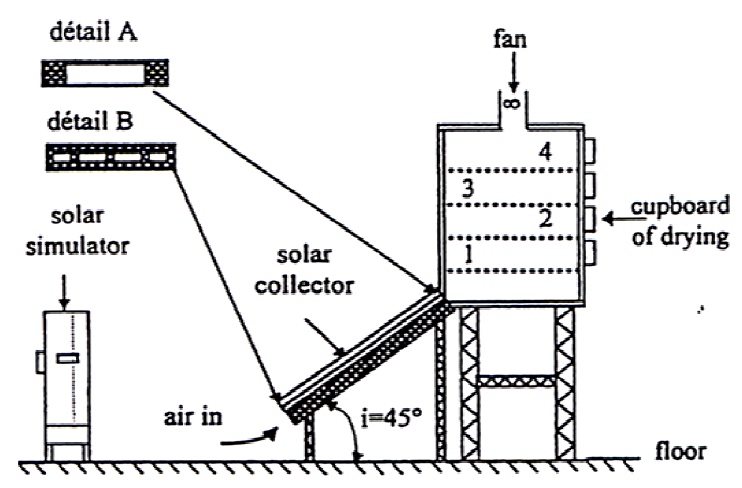

Figure 1. Experimental device.

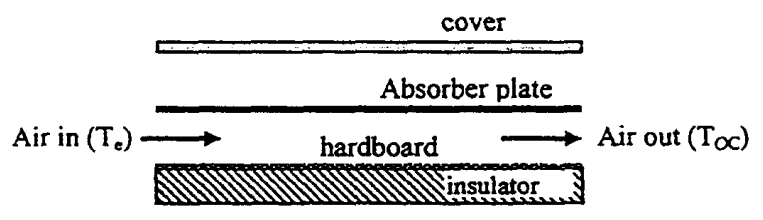

Figure 2. Solar air flat plate collector without obstacles.

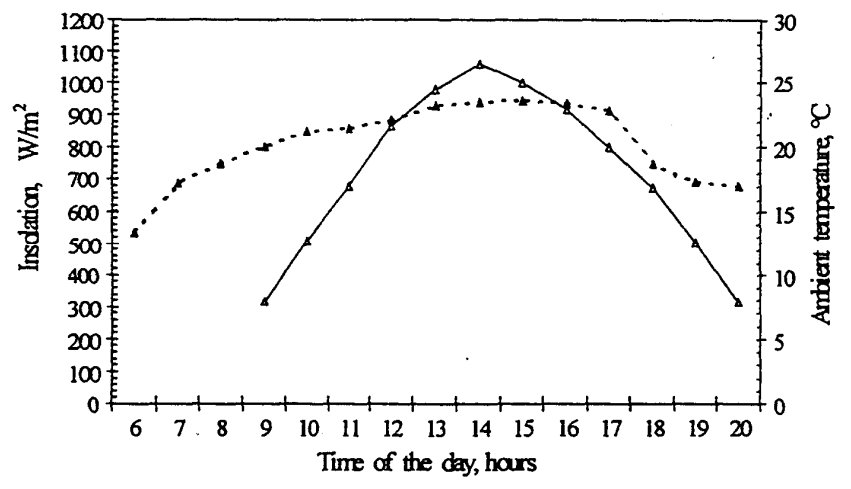

Figure 3. Variation of the ambient temperature and the insolation during the characteristic day of July, at Valenciennes $\_$global hourly insolation $\left(I_{G S}\right) ; \quad \cdot-\bullet$ AMBIENT temperature $\left(T_{a}\right)$.

Too, the shape of the inlet (details A) and outlet (details B) of air of the solar panel have to be carefully arranged so as to avoid heating any dead zones. The baffles are fixed on a hardboard sheet just above the polystyrene plate. The experiments took place at Valenciennes in North-East France, the co-ordinates of which are : latitude $: \varphi=50.3^{\circ}$; altitude $: Z$ $=60 \mathrm{~m}$; longitude $: \mathrm{L}=3.5^{\circ}$, and on a day in July which was considered typical of mean solar time flux (Fig. 3) and which corresponds with the average for the years 1998, 1999 and 2000 [9].

\section{Results and Analysis}

\subsection{Improvements to the Ratio Between Temperature and Thermal Efficiency}

A means of extracting the maximum of heat stored in the absorber is to place baffles in the mobile vein of air; they can be fixed either on the underside of the absorber or onto the 
insulating material, or indeed on both places. The objective is thereby to raise the temperature at the solar panel outlet $\left(\mathrm{T}_{\mathrm{SC}}\right)$, i.e. increasing thermal efficiency, and to reduce charge losses to a minimum [2, 3 and 4, 6, 7 and 8]. Results have been obtained using the solar panel without baffles and subsequently provided with baffles in two stages, firstly with the DCL1 type and then with the OCL1 (Photographs 1 and 2).

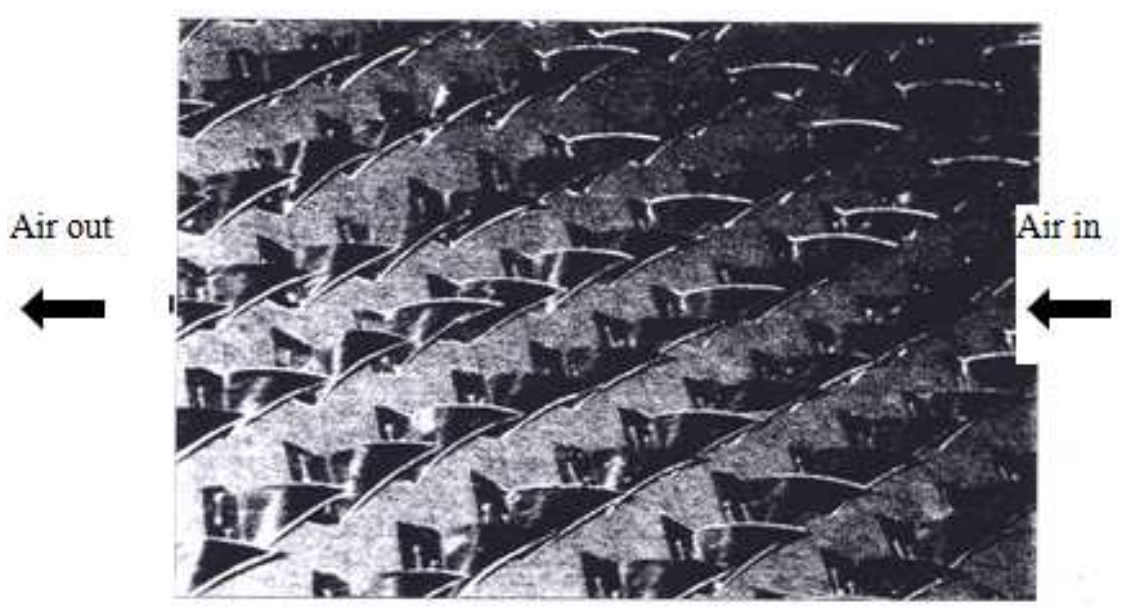

Photograph 1. Layout with DCL1 type baffles.

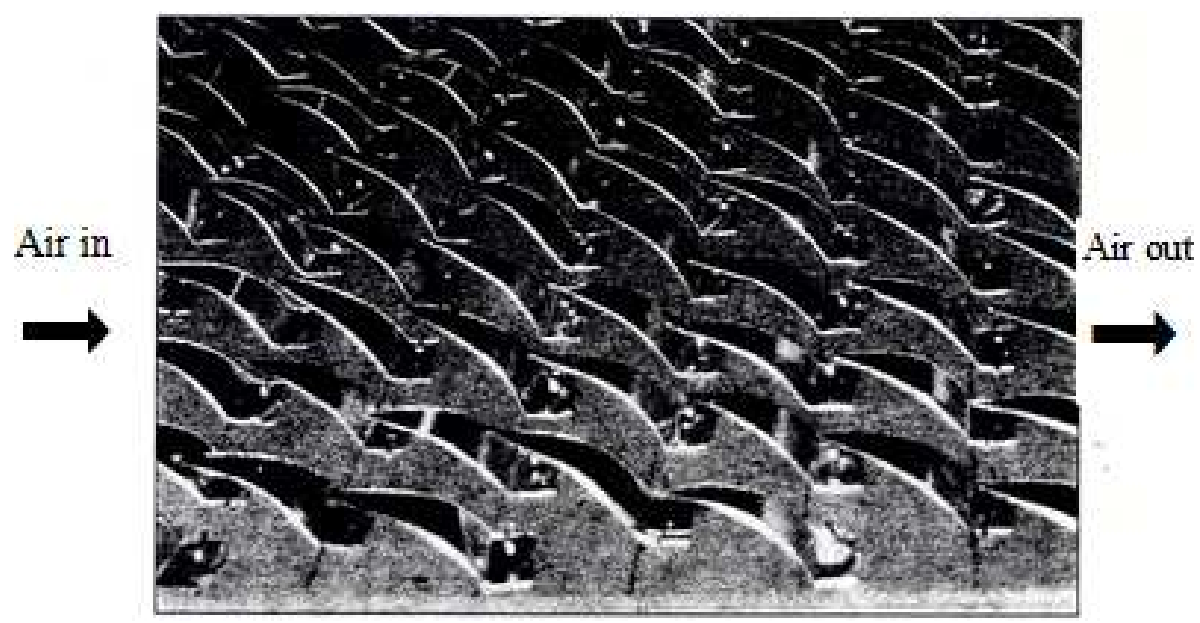

Photograph 2. Layout with OCL1 type baffles.

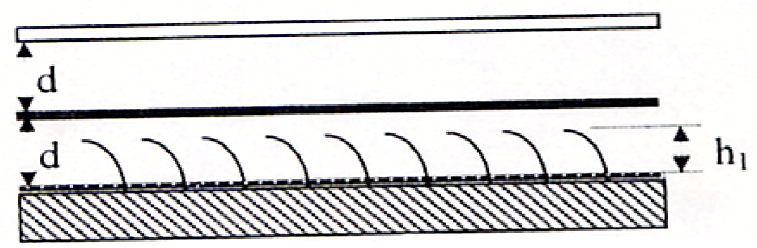

Fig. 4. Solar panel equipped with baffles.

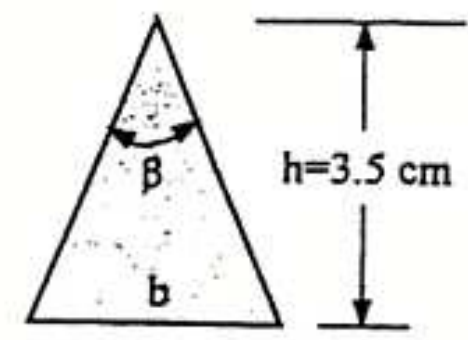

(a)

Delta

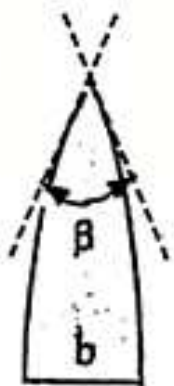

Ogival

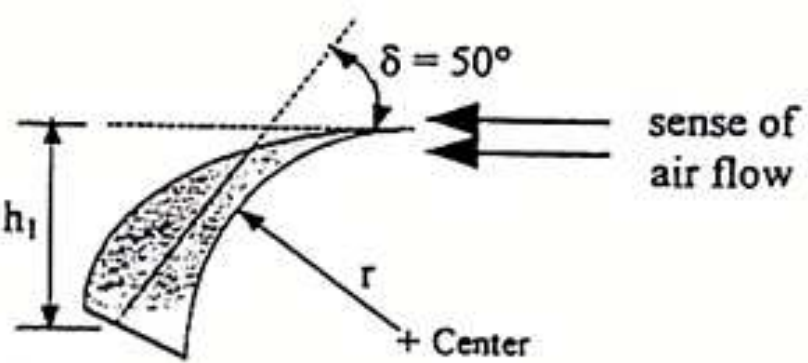

(b)

Figure 5. delta and ogival baffles (a) before bending ; (b) after bending.

The baffles selected for use from the range of shapes already experimented with [10] are formed by bending the otherwise straight delta and ogival wings (Fig. 5a and 5b) $[10-12,27,29]$, and fixing them onto the insulating material (Fig. 4). The apex angle $\beta$ of these baffles is $45^{\circ}$ (Preferential angle) [13].

The index (1) referring to the DCL1 and OCL1 types of 
baffles indicates that the air flow takes place near their tips (Fig. 5b).

Experiments carried out in a wind tunnel [14] have shown that the increase in incidence enables swirling fragmentation to progress continuously on the upper surface of the curved wing. The flow ends in a total disorganisation of the swirling systems at the leak edge of the wing which promotes the creation of a flow of considerable turbulence and, consequently, a better convective thermal interchange, which in turn improves the ratio between temperature and thermal efficiency. Total fragmentation of the swirls takes place at an incidence higher than $65^{\circ}$. The nature of the flow obtained as observed in the wind tunnel has been highlighted

(Photographs $3 \mathrm{a}$ and $3 \mathrm{~b}$ ). Other such visualisations of other shapes of wings $[15,26,28]$ have confirmed results of these differing observations concerning the progressive fragmentation of swirls.

Table 1. Specifications of DCL1 and OCL1 baffles.

\begin{tabular}{lll}
\hline & DCL1 & OCL1 \\
\hline & $45^{\circ}$ & $45^{\circ}$ \\
$\mathrm{H}_{1}(\mathrm{~cm})$ & 1.47 & 1.47 \\
$\mathrm{Et}(\mathrm{cm})$ & 2.3 & 2.0 \\
$\mathrm{E}(\mathrm{cm})$ & 3.5 & 3.5 \\
$\mathrm{~b}(\mathrm{~cm})$ & 3.0 & 1.4 \\
$\mathrm{r}(\mathrm{cm})$ & 4.0 & 4.0 \\
$\mathrm{Ncr}$ & 15 & 22 \\
$\mathrm{Nr}$ & 44 & 44 \\
\hline
\end{tabular}

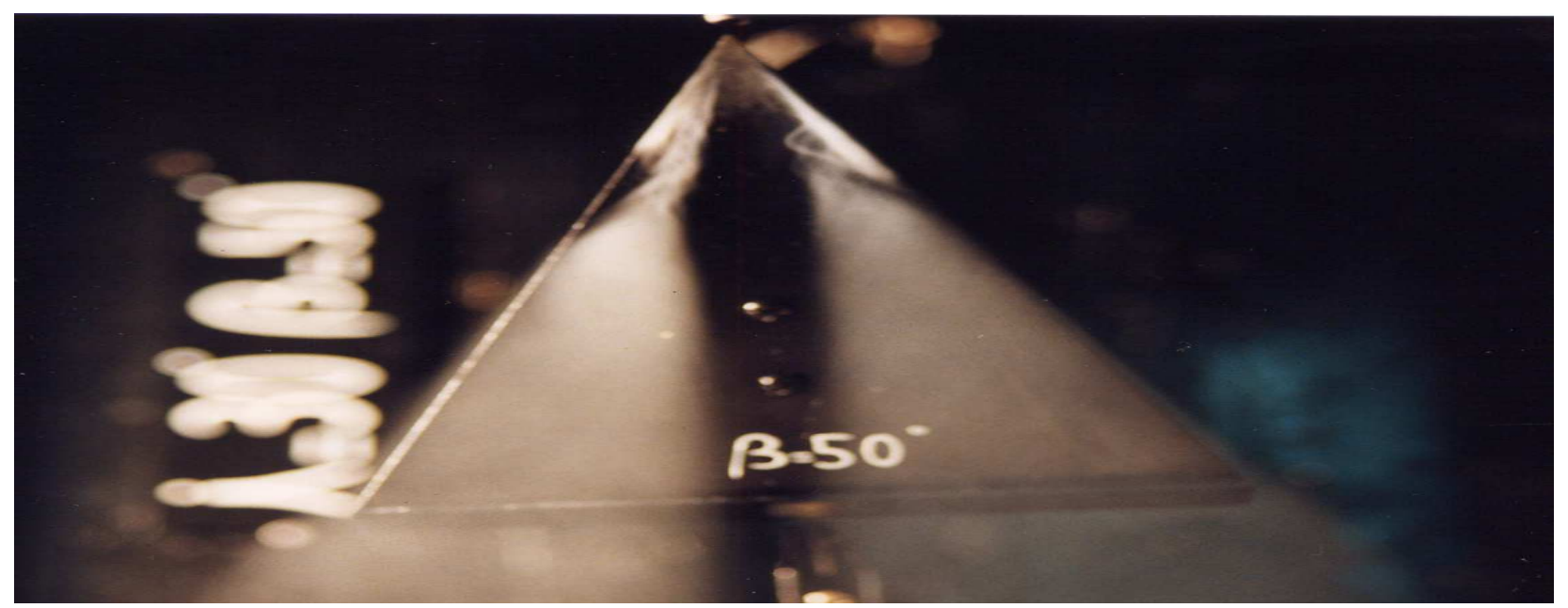

Photograph 3. Visualisation of air flow on the upper surface of the Delta baffle bent longitudinally at an incidence $i$ of $60^{\circ}$, viewed from above.

Prior to a presentation of the results obtained in this first part, an explanation of the mathematical expression used to calculate thermal efficiency is called for. The Letz model [16] has been used as it is one of the most recent and complete formulae, being so because it takes into account not only the relative humidity of the air and the leak-flow of air as it is sucked into the sensor by the ventilator but also the temperatures at the inlet and outlet points of the solar panel. According to prior enthalpy assessment, made by the authors of this paper, of the different modes selected for the experiments, thermal efficiency $(\eta)$ is determined by :

$$
\begin{gathered}
\eta=\frac{\rho \cdot \mathrm{C}_{\mathrm{p}} \cdot \mathrm{Q}_{\mathrm{V}_{\mathrm{a}}} \cdot\left(\mathrm{T}_{\mathrm{sc}}-\mathrm{T}_{\mathrm{e}}\right)}{\mathrm{I}_{\mathrm{GS}} \cdot \mathrm{A}_{\mathrm{C}}} \\
\eta=\frac{\rho \cdot \mathrm{C}_{\mathrm{p}} \cdot \mathrm{Q}_{\mathrm{V}} \cdot\left(\mathrm{T}_{\mathrm{sc}}-\mathrm{T}_{\mathrm{e}}\right)}{\mathrm{I}_{\mathrm{GS}}} \\
\rho=\rho_{\mathrm{o}} \frac{273}{273+\mathrm{T}_{\mathrm{SV}}} \frac{\mathrm{P}(\mathrm{Z})}{\mathrm{P}_{0}}
\end{gathered}
$$

where $\mathrm{P}(\mathrm{Z}) / \mathrm{PO}=(0.88)^{\mathrm{Z}}$ and for Valenciennes $\mathrm{P}(\mathrm{Z}) / \mathrm{PO} \approx 1$ $\rho_{\mathrm{o}}=1.293 \mathrm{Kg} / \mathrm{m} 3$ and $\mathrm{C}_{\mathrm{P}}=1005 \mathrm{~J} / \mathrm{Kg} . \mathrm{K}$.
The captive surface $A_{C}$ is $1.28 \mathrm{~m}^{2}$. In our case, thermal efficiency $(\eta)$ is given for a constant global solar flow $\left(\mathrm{I}_{\mathrm{GS}}\right)$ of $1063.5 \mathrm{~W} / \mathrm{m}^{2}$ corresponding to solar midday. Therefore, for a specific flow of $35 \mathrm{~m}^{3} / \mathrm{h} \cdot \mathrm{m}^{2}, 54 \%$ thermal efficiency was obtained in the case of the solar panel provided with DCL1 baffles. By increasing the flow to $70 \mathrm{~m}^{3} / \mathrm{h} \cdot \mathrm{m}^{2}, 80 \%$ thermal efficiency was achieved. In the case of the solar panel without baffles, the respective thermal efficiency percentages obtained with each of the two flows were only $35 \%$ and $55 \%$ (Fig. 6) for temperatures at the solar panel outlet $\left(\mathrm{T}_{\mathrm{WB}}\right)$ of $61.7^{\circ} \mathrm{C}$ and $53.3^{\circ} \mathrm{C}$ as opposed to $82.8^{\circ} \mathrm{C}$ and $66.3^{\circ} \mathrm{C}$ in the case of a solar panel provided with DCL1 baffles. However, under the same conditions as above, but using OCL1 baffles, slightly lower results were obtained than those with DCL1 ones. This can be explained by the fact that the air flow section differs and so, and in particular, the progressive fragmentation of swirls occurs a little earlier. Indeed, for the same flows, the respective thermal efficiency percentages are $52 \%$ and $76 \%$ and correspond to temperatures $\left(\mathrm{T}_{\mathrm{WB}}\right)$ of $81.3^{\circ} \mathrm{C}$ and $64.8^{\circ} \mathrm{C}$. With these configurations using DCL1 and OCL1 type baffles, $50 \%$ thermal efficiency is obtained respectively with flows of $32 \mathrm{~m}^{3} / \mathrm{h} \cdot \mathrm{m}^{2}$ and $33 \mathrm{~m}^{3} / \mathrm{h} \cdot \mathrm{m}^{2}$ as opposed to $58 \mathrm{~m}^{3} / \mathrm{h} . \mathrm{m}^{2}$ when using an SC solar panel where relative flow reductions are respectively $44.8 \%$ and $43.1 \%$. The respective temperatures $\left(\mathrm{T}_{\mathrm{WB}}\right)$ are $84.5^{\circ} \mathrm{C}$ and $82^{\circ} \mathrm{C}$ as opposed to $55^{\circ} \mathrm{C}$. The latter correspond to respective temperature rises $\left(\Delta \mathrm{T}=\mathrm{T}_{\mathrm{WB}}-\mathrm{T}_{\mathrm{e}}\right)$ of $56.1^{\circ} \mathrm{C}$ and $54^{\circ} \mathrm{C}$ as opposed to $27.2^{\circ} \mathrm{C}$. In both cases, the 
amounts of charge losses are acceptable.

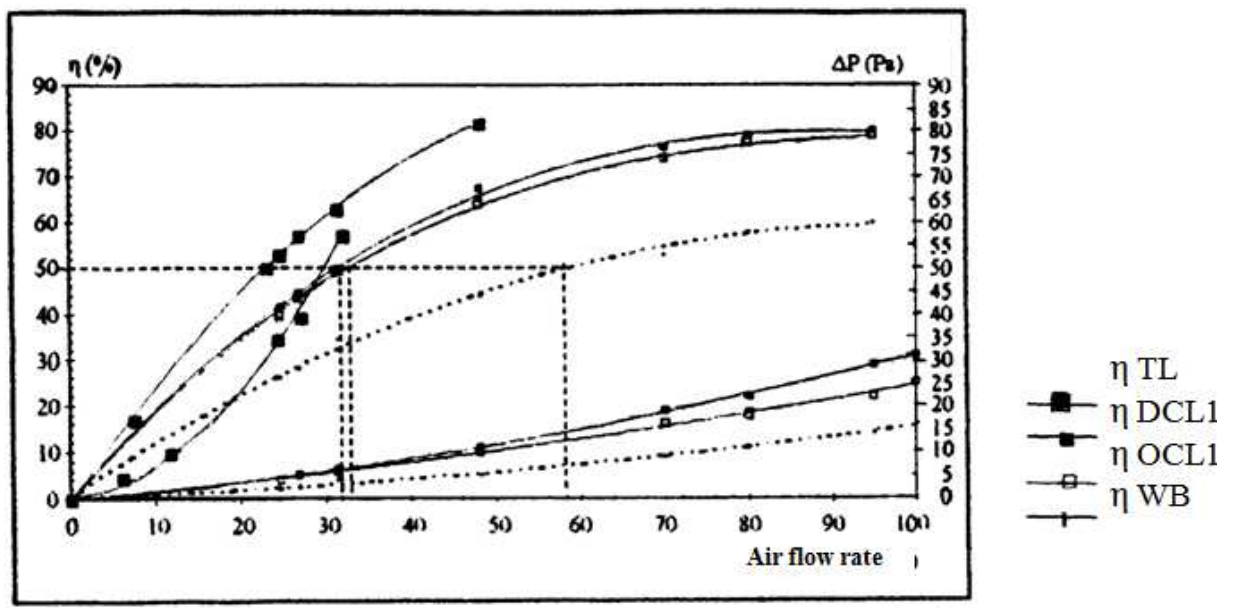

Fig. 6. Evolution of thermal efficiency (where $I_{G S}=1063.5 \mathrm{~W} / \mathrm{m}^{2}$ ) and charge losses in relation to air flow as concerns WB solar panels and those provided with different types of baffles (i.e. DCL1, OCL1 and then TL), as at the Valenciennes site.

However, the blocking effect of TL baffles enables a very turbulent flow to be created and, consequently, provides a very good level of thermal interchange. It is worth noting that the resultant charge losses are very high because the air flow through the duct is very weak compared with that attained with other types of baffles. A thermal efficiency of $50 \%$ obtained with a specific flow of $23 \mathrm{~m} / \mathrm{h} \cdot \mathrm{m}^{2}$ corresponds to a temperature $\left(\mathrm{T}_{\mathrm{WB}}\right)$ of $104^{\circ} \mathrm{C}$, i.e. an improvement in temperature $\left(\mathrm{T}_{\mathrm{e}}\right)$ of $75^{\circ} \mathrm{C}$ at the solar panel inlet. These results are decidedly better than those obtained when using DCL1 or OCL1 type baffles. The lengthening of the distance covered by the air in the solar panel duct results in an even better interchange of heat between the coolant air and the absorber.

\subsection{Improving Drying Time}

Dating from the early research work of Lewis in 1921 [17] and Sherwood in 1929 [18], techniques of drying have been the subject of many scientific publications and continues to be a priority field of research, especially in respect of countries where traditional methods remain in use and are essential for want of better. As it is readily available at little or no running costs compared with other sources of energy such as electric resistors [19], solar energy is obviously an alternative. At Valenciennes, simulated solar energy was used to carry out experiments applied to drying pre-dried papayes; the simulator was conceived to provide conditions of a typical July day.

For solar energy to be harnessed effectively, certain difficulties have first to be overcome and to be achieved with the help of technically viable and economically profitable systems. The choice of the type of dryer is conditioned by whether or not the product in question can withstand solar radiation; it also has to be made between direct or indirect dryers and depends, too, on the commercial value of the product. Since the performances of absorbers are higher than the thermal conversion capacity of the product, the use of an indirect dryer is the more effective. The system under study is therefore an indirect solar dryer functioning by thermal forced convection.

The construction of a drying installation is very complex and requires the taking into account of a number of parameters and the mastering of many phenomena before it can be devised. For it to work efficiently, it is necessary, first of all, to estimate the quantities of products to be treated and then to carry out a thorough study of the design of the system. What is important, from the thermal point of view and to ensure that the components of the installation are optimised, is to evaluate the various modes of transfer and to assess the energy-giving potential while taking into account the coupling between the warm air generator and the drying unit with a view to its dimensional set-up. In our experiment, the device (Fig. 1), being constructed with only one plane solar panel and a "drying cupboard" holding four trays $\{$ i.e. a simplified version of a sort of kiln\}, has been designed to treat small quantities of products and, consequently, equipping it also with means for storing energy; with an auxiliary heating system and with a device for recycling air is therefore unnecessary.

The quantities of heat $\left(\mathrm{Q}_{\mathrm{u}}\right)$ recovered by the coolant fluid, as far as the absorber is concerned, depends on the efficiency of the solar panel used. Given that these quantities are proportional to the variations in temperature between the inlet and the outlet of the solar panel, the results presented above show that a solar panel provided with baffles functions more efficiently and so baffles are essential fittings because they reduce drying times.

In our experimental work, the objective is to carry out drying by a simulation of solar energy. However, for a given air flow, we wanted to study the variations in certain parameters of the drying process as at different times during the typical day under consideration. In view of the considerable expenditure that could be involved in setting up a real-life operation, the use of thermal forced convection would seem to be less suitable in applying the findings of our small-scale experiment to a large-scale situation. Nevertheless, it would be profitable to take advantage of natural convection in a solar chimney. Its application is, of course, all the more 
valid in geographical zones deprived of electrical power. The choice between forced and natural convection depends on several factors, in particular on the quantity of the product to be treated, on the capillary structure of that product and its nutritional value while not neglecting the financial budget available. Drying time is indeed of paramount importance. As regards large-scale \{industrial\} concerns, an external source of energy is required. Where electrical power is available, even if weak but at an affordable rate, it is logical to make use of it to actuate the ventilators, blowers or other devices necessary to increase the efficiency of the system. Where a system functions with natural convection in a solar chimney, the driving force of gravity is created by differences in the density of air between the exterior \{ambient conditions \} and the interior of the chimney. The height of the chimney, which influences the efficiency of extracting air, is a factor that has therefore to be adequately investigated. Pasumarthi and Sherif [20] have shown that for a given height and an increasing solar flux, the temperature at one and the same given point in the chimney also increases. Heat interchange improves but the total charge losses of the system, which are proportional to the height of the chimney and to the differences in air density, increase considerably.

Prior to setting out the findings of our experiments, a brief description of the type of TL baffles used is called for. The height of the large (transversal) baffle is $2.5 \mathrm{~cm}$ and that of the small (longitudinal) one is $2 \mathrm{~cm}$ (Fig. 7). The surface $A_{C}$ is 1.28 $\mathrm{m}^{2}$.

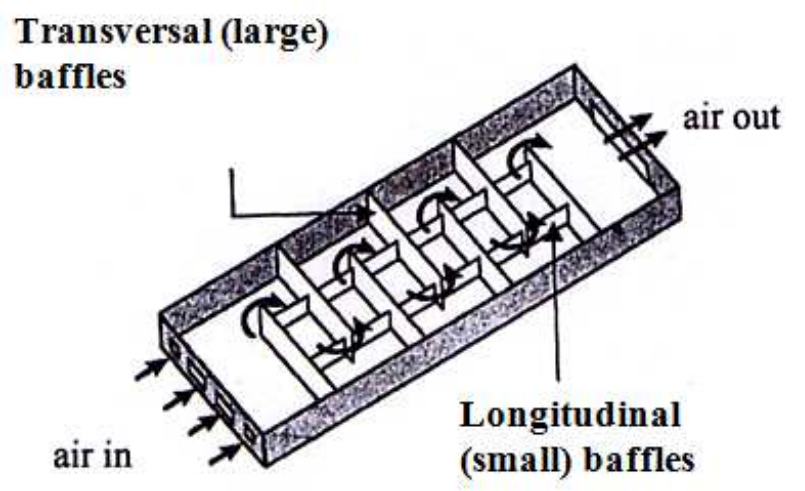

Fig. 7. Solar panel equipped with TL type baffles [Kge/KgMS : kilograms of water per kilograms of dried mass of the product].

\section{$\mathrm{X}_{\mathrm{bS}}$ (Kgwater/KgDS)}

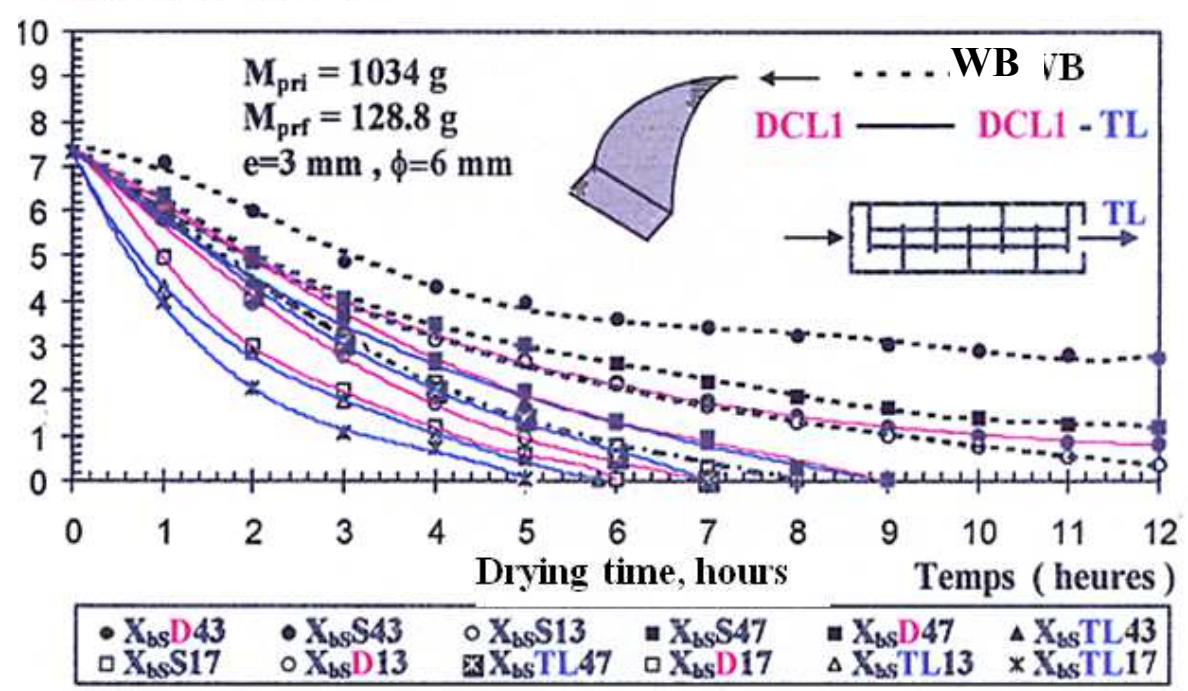

Fig. 8. Evolution of the water content $\left(X_{b S}\right)$ in relation to drying time measured at the first and fourth trays with flows of $31.3 m^{3} / h^{2} m^{2}$ and $70 m^{3} / h . m^{2}$ using $W B$, DCL1 and TL type solar panels, data recorded on a typical July day at the Valenciennes site.

To study the influence of the flow of drying air on drying time, it was considered of value to use two flows, one of $31.3 \mathrm{~m}^{3} / \mathrm{h} \cdot \mathrm{m}^{2}$, the other of $70 \mathrm{~m}^{3} / \mathrm{h} \cdot \mathrm{m}^{2}$. This adjustment is made with the help of a ventilator (solar simulator). The air flow is measured using a "Jules et Richard" anemometer with a $10 \mathrm{~cm}$ diameter propeller. With a flow of $31.3 \mathrm{~m}^{3} / \mathrm{h} . \mathrm{m}^{2}$, drying times at the first (bottom) tray (Fig. 1) take up to 8 hours as regards the solar panel fitted with DCL1 baffles, 6 hours 35 minutes for that with TL baffles while the longest time taken was with the WB solar panel. There are therefore reductions of drying time of $49 \%$ and $59 \%$ in comparison with the WB solar panel. The final content of water collected in the WB solar panel is only attained after 14 hours 10 minutes of drying time (Fig. 8). The air coming from the level of the first tray is still heavy with moisture and, consequently, for this same air flow, drying time at the level of the fourth (top) tray takes longer for all three types of solar panels used. By increasing the flow to $70 \mathrm{~m}^{3} / \mathrm{h} . \mathrm{m}^{2}$, drying times decrease in each of the three solar panels. As drying is brought about by force of speed of the flow, this faster flow results in a more rapid evacuation of the moist air.

By increasing the flow from $31.3 \mathrm{~m}^{3} / \mathrm{h} \cdot \mathrm{m}^{2}$ to $70 \mathrm{~m}^{3} / \mathrm{h} \cdot \mathrm{m}^{2}$, and as regards the solar panel with DCL1 baffles, the drying time at the first tray is reduced by one hour, i.e. a relative reduction of $15 \%$ whereas a relative reduction of $13.8 \%$ is attained using a solar panel with TL baffles. The drying times at the level of the fourth tray are respectively 10 hours (DCL1 baffles) and 8 hours (TL baffles). Comparing these results 
with the performance of the solar panel without baffles, and with a flow of $70 \mathrm{~m}^{3} / \mathrm{h} \cdot \mathrm{m}^{2}$, the reductions in drying times at the first tray are respectively $27 \%$ and $39.5 \%$.

A graph (Fig. 9) plots the evolution of the loss of mass $(\Delta M)$ at each hour, for each of the two flows and for each of the types of solar panel used. Fig. 10 shows the evolution in temperature of the product $\left(\mathrm{T}_{\mathrm{Pr}}\right)$ in relation to the passage of time during the drying process. It is to be noted that for every type of solar panel used, drying takes place at temperatures that vary in accordance with the solar time flux particular to the day on which the experiment is conducted. In every case, a constant phase of drying cannot therefore exist (Fig. 11).

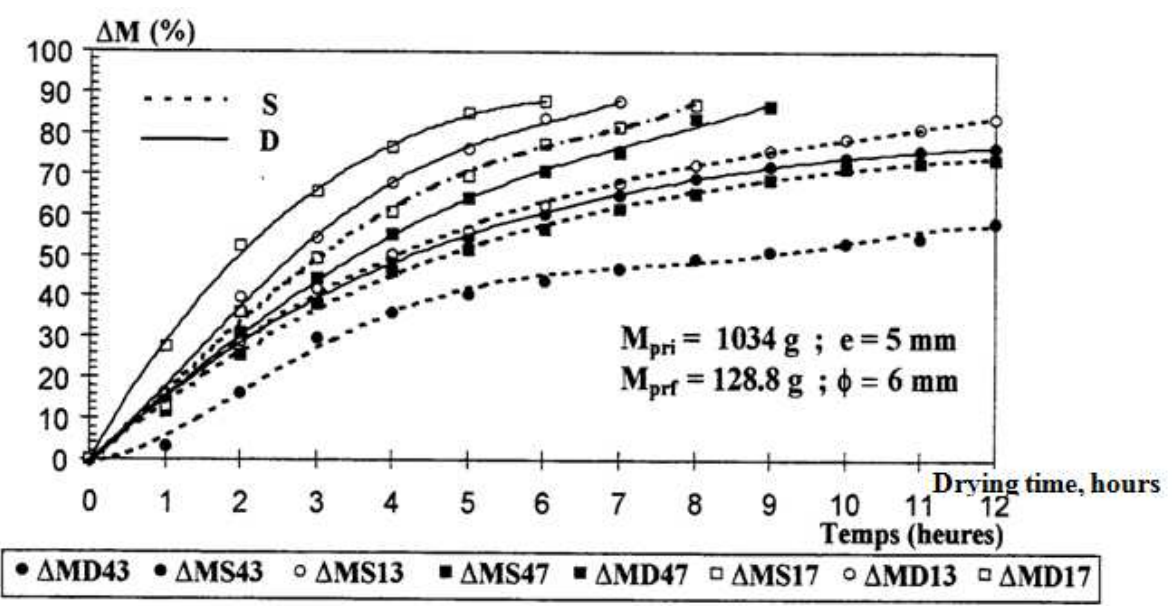

Fig. 9. Evolution of the loss of mass $(\Delta M)$ of plums in relation to drying time measured at the first and fourth trays with flows of $31.3 m^{3} / h^{2} m^{2}$ and $70 m^{3} / h^{2} m^{2}$ using DCL1 and TL type solar panels, data recorded on a typical July day at the Valenciennes site.

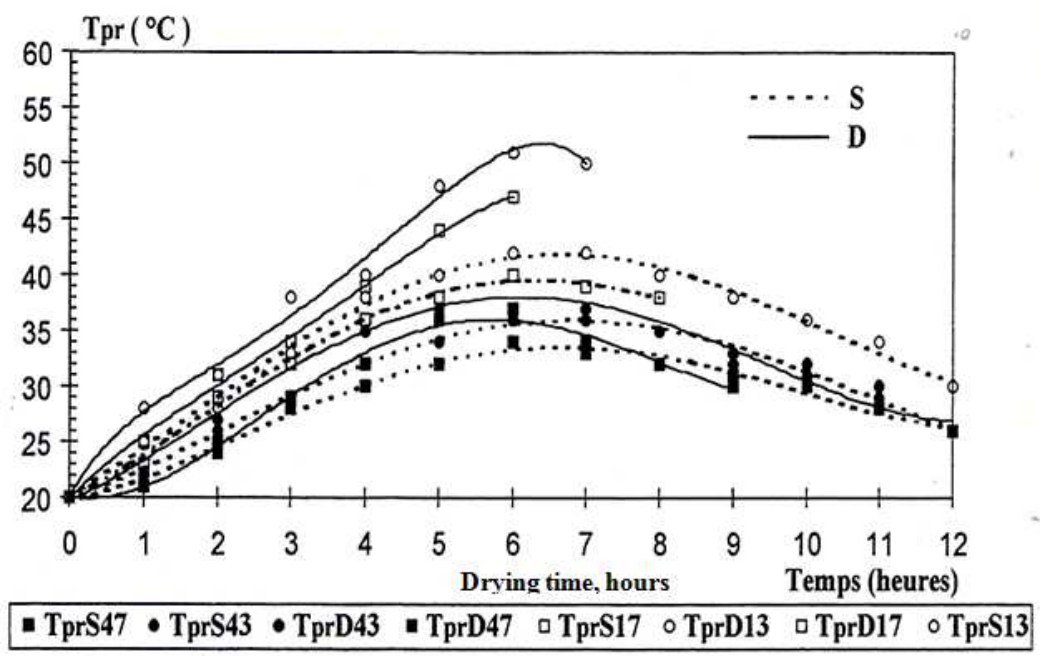

Fig. 10. Evolution of the temperature of papayes in relation to drying time measured at the first and fourth trays with flows of $31.3 m^{3} / h^{\prime} m^{2}$ and $70 m^{3} / h . m^{2}$ using $W B, D C L 1$ and TL type solar panels.

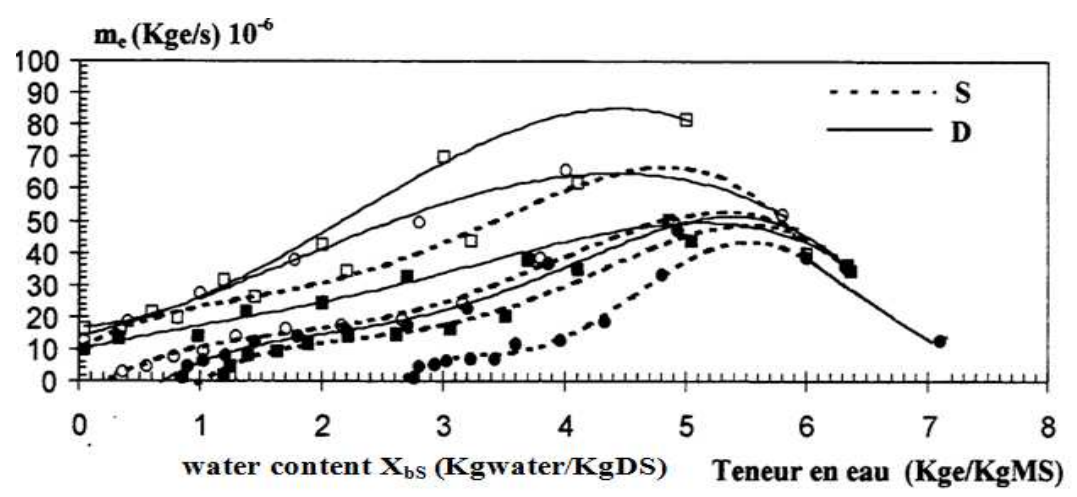

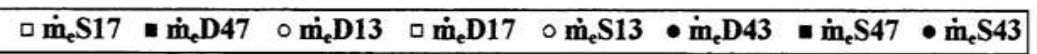

Fig. 11. Evolution of the drying speed $\left(m_{e}\right)$ in relation to water content to the point when the product is completely dried with flows of $31.3 m^{3} / h^{2} m^{2}$ and $70 m^{3} / h . m^{2}$ using WB and DCL1 type solar panels. 
Analysis of the findings relative to the WB solar panel (without baffles), reveals that functioning with a low air flow is considerably more efficient because of the reduction in drying time. The mechanical power consumed $\left(\mathrm{P}_{\mathrm{mc}}\right)$ by the ventilator is proportional to charge losses and to the air flow in the dynamic air vein of the panel. This same power is expressed by :

$$
\mathrm{P}_{\mathrm{mc}}=\Delta \mathrm{P} \cdot \mathrm{Q}_{\mathrm{V}}=\zeta \cdot \mathrm{Qv}^{3}
$$

where $\zeta$ is the factor of friction, characteristic of artificial rough places (baffles)

As the relationship between the two flows is 2.24 , the power is therefore increased by a factor of 11.24 , a fact which further highlights preference for using a low flow. In spite of the recommendations made by some research workers not to exceed a drying air temperature of $55^{\circ} \mathrm{C}$, higher temperatures were used in our experiments (at around solar midday). However, at temperatures above $70^{\circ} \mathrm{C}$, reddening spots (i.e. signs of burning) appeared on the products. Indeed, the quality, colour, savour and nutritional value of the product are all closely subjected to conditioning by the thermal process. Consequently, to create ideal drying conditions at temperatures lower than those recommended for the product in question, some precautions can be taken such as :

- install a temperature indicator at the inlet to the "drying cupboard" and use a higher air flow if necessary to reduce the temperature while bearing in mind that should the increase in the air flow become imperative at midday, it would not be so when the sun is less high and its rays more oblique in relation to the position of the solar panel, i.e. in the early morning and late afternoon.

- install a temperature regulator adjusted to provide a constant drying air temperature of $55^{\circ} \mathrm{C}$.

The quantities of heat available for use and reclaimed at the solar panel outlet are much higher when using solar panels equipped with TL baffles than those with DCL1 baffles. Variations in those quantities $\left(\mathrm{Q}_{\mathrm{u}}\right)$, in global quantities of drying heat $\left(\mathrm{Q}_{\mathrm{s}}\right)$ and their differences $\left(\Delta \mathrm{Q}=\mathrm{Q}_{\mathrm{u}}-\mathrm{Q}_{\mathrm{s}}\right)$ are shown in Fig. 12 (for WB solar panels without baffles) and Fig. 13 (solar panels equipped with DCL1 baffles). Worthy of note is the fact that the quantities of heat available for use are increased by a factor of approximately 1.65 as regards the performance of the SC solar panel. The differences in quantities $(\Delta \mathrm{Q})$ are of some consequence because they are, in fact, surplus to normal requirements for the drying process and can therefore be stored and made available for use, for example, during the night or on days when sunlight is mediocre $[22,23,24,25]$. This excess of heating needs can be kept in underground ducts and thus ready for use when needed.

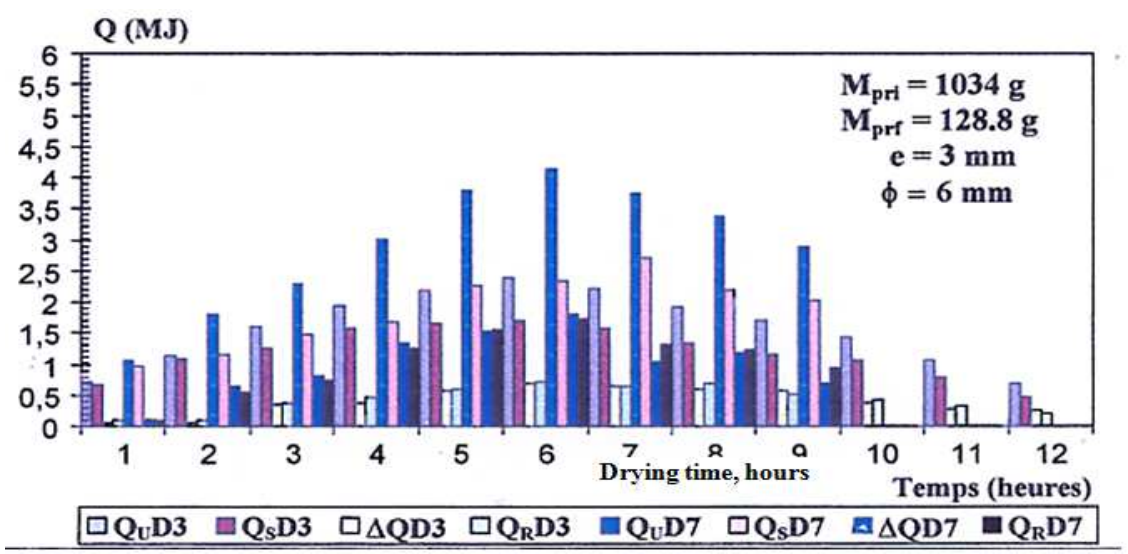

Fig. 12. Variations in quantities of heat (Q) in relation to drying time with flows of $31.3 \mathrm{~m}^{3} / \mathrm{h}^{\mathrm{m}} \mathrm{m}^{2}$ and $70 \mathrm{~m}^{3} / \mathrm{h} . \mathrm{m}^{2}$ using an WB type solar panel (without baffles).

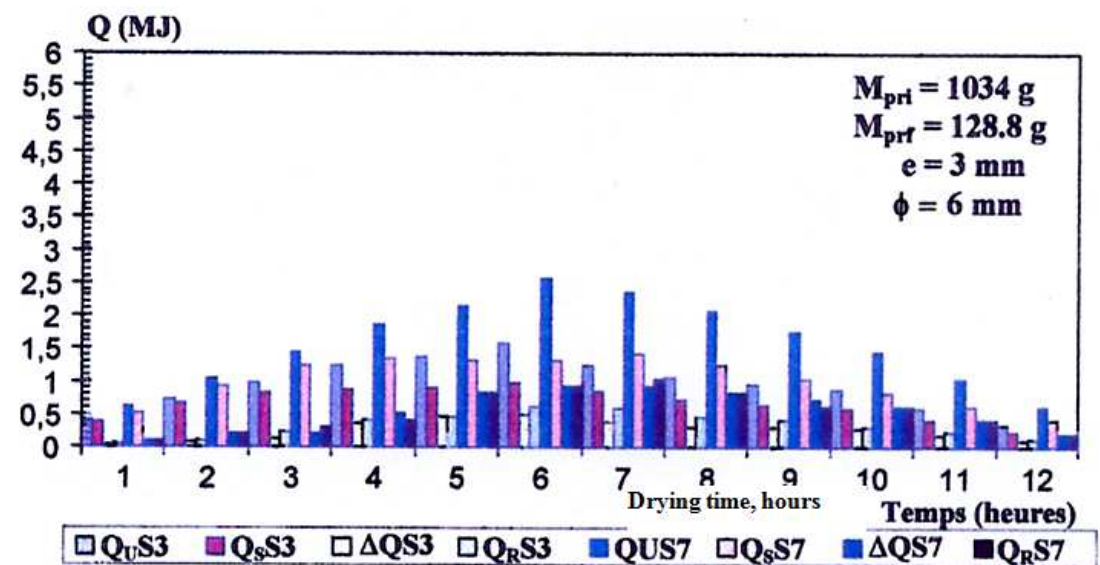

Fig. 13. Variations in quantities of heat $(Q)$ in relation to drying time with flows of $31.3 \mathrm{~m}^{3} / \mathrm{h} . \mathrm{m}^{2}$ and $70 \mathrm{~m}^{3} / \mathrm{h} . \mathrm{m}^{2}$ using a solar panel equipped with DCL1 baffles. 


\section{Conclusion}

It can de deduced from the findings of our experiments using various types of solar panels that the placing of baffles in the air vein is a very significant factor which serves to improve the performance of a given solar panel. Several determinants have, of course, to be taken into consideration to include the shapes and dimensions of the baffles, the number of rows and their layout. The study has shown that a solar panel equipped with baffles not only appreciably improves the ratio between temperature and thermal efficiency but also reduces drying time of the product. Also noteworthy is the fact that a reduction in transversal $(\mathrm{Et})$ and longitudinal $(\mathrm{E} l)$ spaces contributes considerably to the quality of the results. Moreover, an increase in the angle $(\Delta \mathrm{i})$ brings about even better results. However, some constraints imposed by the nature of the finished product such as its quality, savour, colour and nutritional value, have to be taken into account in determining what constitutes the ideal temperature of drying air.

\section{Nomenclature}

$\mathrm{A}_{\mathrm{C}}$ : surface activates plane solar collector $\left[\mathrm{m}^{2}\right]$

b: width of the baffles at the base

b': coefficient of blocking

$\mathrm{C}_{\mathrm{p}}$ : heat capacity of the air $[\mathrm{J} / \mathrm{Kg} . \mathrm{K}$ ]

$\mathrm{d}$ : outdistance between the absorber and the cover or the insulator

$\mathrm{E} \ell$ : longitudinal space between lines of baffles

Et: space transverse between two baffles of the same line $\mathrm{h}$ : initial height of the baffles

$\mathrm{h}_{1}$ : swing-over bed of the baffles compared to the insulator

$h_{\text {ccf }}$ : coefficient of convectif heat exchange enters the air and the absorber [ W/K.m ${ }^{2}$ ]

$\mathrm{I}_{\mathrm{GS}}$ : total time solar flow of simulation $\left[\mathrm{W} / \mathrm{m}^{2}\right.$ ]

$\mathrm{K}_{\mathrm{a}}, \mathrm{K}_{\mathrm{IS}}$ : thermal conductivity of the absorber and the insulator [ $\mathrm{W} / \mathrm{m} . \mathrm{K}$ ]

$\mathrm{L}$ : longitude of the place [ degrees ]

$\mathrm{Z}$ : altitude of place $[\mathrm{km}$ ]

$\ell$ : width of the vein $[\mathrm{m}]$

$\mathrm{m}_{\mathrm{e}}$ : speed of drying $[\mathrm{Kg} / \mathrm{s}$ ]

$\mathrm{N}_{\mathrm{Cr}}, \mathrm{N}_{\mathrm{r}}$ : a number of baffles per line and a number of lines

Pmc: consumed mechanical power of the ventilator [ $\mathrm{W}$ ]

Po, $\mathrm{P}(\mathrm{Z})$ : pressure atm on the sea level (10.13 105 Pa) and with altitude $\mathrm{Z}$ of place [ $\mathrm{Pa}$ ]

$\mathrm{Q}_{\mathrm{Va}}$ : volume throughput of the air in the sensor $\left[\mathrm{m}^{3} / \mathrm{h}\right.$ ]

$\mathrm{Q}_{\mathrm{V}}$ : volume throughput of the air per unit of area $\left[\mathrm{m}^{3} / \mathrm{h} . \mathrm{m}^{2}\right]$

$\mathrm{Q}_{\mathrm{u}}$ : quantity of useful heat on the outlet side of sensor [ $\left.\mathrm{MJ}\right]$

$\mathrm{Q}_{\mathrm{s}}$ : quantity of heat of drying of product [ $\left.\mathrm{MJ}\right]$

r: ray of bending of the baffles

Re: Reynolds number

$\mathrm{S}_{\text {mini }}$ : minimal bypass section of the air in the vein $\left[\mathrm{m}^{2}\right]$

$\mathrm{T}_{\mathrm{SV}}, \mathrm{T}_{\mathrm{a}}$ : temperature at the exit of the ventilator and the ambient air $\left[{ }^{\circ} \mathrm{C}\right]$
$\mathrm{T}_{\mathrm{e}}, \mathrm{T}_{\mathrm{SC}}$ : temperature of the air at the entry and the outlet side of the sensor $\left[{ }^{\circ} \mathrm{C}\right.$ ]

$\mathrm{T}_{\mathrm{Pr}}$ : temperature on the level of the surface of the product $\left[{ }^{\circ} \mathrm{C}\right]$

$\mathrm{V}_{\mathrm{m}}$ : maximum speed of the air flow in the vein $[\mathrm{m} / \mathrm{s}$ ]

$\mathrm{X}_{\mathrm{bS}}$ : water content at base dries of the product [ $\mathrm{Kg} / \mathrm{KgMS}$ ]

$\mathrm{X}_{\mathrm{ObS}}, \mathrm{X}_{\mathrm{fbS}}$ : water content initial and final at base dries

[ $\mathrm{Kg} / \mathrm{KgMS}$ ]

Greek Letters:

$\alpha$ : angle of inclination of the sensor compared to the ground [ degrees ]

$\beta$ : angle of apex (or at the top) of the baffles [ degrees ]

$\varepsilon_{\mathrm{c}}$ : coefficient of emissivity of the cover

$\varphi$ : latitude of the place [ degrees ]

$v$ : viscosity kinematic of the $\operatorname{air}\left[\mathrm{m}^{2} / \mathrm{s}\right]$

$\rho_{0}, \rho$ : masse voluminal of the air on the sea level and altitude $\mathrm{Z}$ of the place $\left[\mathrm{Kg} / \mathrm{m}^{3}\right.$ ]

$\eta, \eta_{t}$ : output of the plane solar collector and thermal efficiency of the system of drying [\% ]

$\tau_{\mathrm{C}}$ : coefficient of transmission of cover

$\zeta$ : factor of friction characterizing artificial roughnesses (obstacles)

$\Delta \mathrm{i}$ : angle of bending of the baffles [ degrees ]

$\Delta \mathrm{M}:$ loss of mass of the product [ $\%$ ]

$\Delta \mathrm{P}:$ pressure losses in the vein of sensor $[\mathrm{Pa}]$

$\Delta \mathrm{Q}$ :quantity heat excédentaire[MJ ]

Notations:

DCL1 : Forme of the baffles in the mobile vein of air: Delta and Curved Longitudinally with the flow attacking by point

OCL1 : Forme baffles in the mobile vein of air: Ogival Curved Longitudinally with the flow attacking by point

WB, TL : Without Baffles and Transversal-Longitudinal baffles

$\eta \mathrm{S}:$ Rendement of sensor WB

$\eta \mathrm{D}$ : Rendement of the sensor provided with baffles DCL1

$\eta T L$ : Rendement of the sensor provided with baffles TL

$\mathrm{X}_{\mathrm{bS}} \mathrm{TL} 13$ : Tenor out of water at dry base in the case with the sensor provided with baffles TL, on the level of the 1st tray, using the flow of $31.3 \mathrm{~m}^{3} / \mathrm{h} . \mathrm{m}^{2}$

$\triangle \mathrm{MD} 13:$ Perte of mass of the product in the case of the sensor provided with baffles DCL1, on the level of the 1st tray, using the flow of $31.3 \mathrm{~m}^{3} / \mathrm{h} \cdot \mathrm{m}^{2}$

$\mathrm{T}_{\mathrm{pr}} \mathrm{S} 17$ : Temperature of the product in the case of sensor $\mathrm{WB}$, on the level of the $1 \mathrm{st}$ tray, using the flow of $70 \mathrm{~m}^{3} / \mathrm{h} . \mathrm{m}^{2}$.

$\mathrm{m}_{\mathrm{e}} \mathrm{D} 47$ : Speed of drying in the case of the sensor provided with baffles DCL1, on the level of the 4th tray, using the flow of $70 \mathrm{~m}^{3} / \mathrm{h} \cdot \mathrm{m}^{2}$

$\mathrm{Q}_{\mathrm{u}} \mathrm{S} 3$ : Quantity of useful heat, in the case of sensor WB, using the flow of $31.3 \mathrm{~m}^{3} / \mathrm{h} . \mathrm{m}^{2}$

$\mathrm{Q}_{\mathrm{S}} \mathrm{D} 7$ : Quantity of heat of drying, in the case of the sensor provided with baffles DCL1, using the flow of $70 \mathrm{~m}^{3} / \mathrm{h} . \mathrm{m}^{2}$.

\section{References}

[1] Zugary M.R., Vullierne J.J., "Amélioration des performances thermiques d'un capteur solaire par l'utilisation d'une structure à lamelles", Entropie,n¹76,(1993), pp25-30. 
[2] Ouard S., "Optimisation des formes et disposition d'obstacles dans la veine mobile du fluide des capteurs solaires plans à deux couches d'air en vue de la maximisation du couple rendement et température", thèse doctorat, Valenciennes, (1989).

[3] Moummi N., "Prévisions systématiques et optimisation des performances des capteurs solaires plans à air dans divers sites de climats Méditerranéens ou sahariens et avec ou sans altitudes", thèse doctorat, Valenciennes, (1994).

[4] Ben Slama R., "Contribution à l'étude et au développement de pompes et capteurs solaires", thèse doctorat, Valenciennes, (1987).

[5] Choudhury C., Gary H.P., Performance of air heating collectors with packed airflow passage", Solar Energy, V 50,3, (1993), pp 205-221.

[6] Gbaha P., "Etude et optimisation des échanges thermiques et des performances des capteurs solaires plans à deux veines d'air", thèse doct, Valenciennes, (1989).

[7] Hachemi A., "Contribution à l'optimisation des performances thermiques des insolateurs plans à air à lit garni de rangées d'obstacles aux pas serrés, amélioration du rendement par interaction entre rayonnement et convection", thèse doctorat, Valenciennes (1992).

[8] Moummi A., "Etude globale et locale du rôle de la géométrie dans l'optimisation des capteurs solaires plans à air", thèse doctorat, Valenciennes, (1994).

[9] Météo France, Direction Régionale, Villeneuve d'Ascq, Lille, (2002).

[10] Ahmed-Zaid A., "Optimisation des capteurs solaires plans à air. Application au séchage de produits agricoles et de la pêche", thèse doctorat, (1998)

[11] Messaoudi H., Ahmed-Zaid, Le Ray M. "Le rôle de la géométrie dans l'amélioration ou la diminution des échanges thermiques turbulents dans les capteurs solaires à air", $3^{\text {eme }}$ congrès de mécanique, Société Marocaine des Sciences Mécaniques et de l'université Abdelmalek Essaadi, Faculté Science de Tétouan, VI,(22-25 avril 97),pp637-644.

[12] Ahmed-Zaid A., Messaoudi H., Benoyounes R., Le Ray M, "Etude expérimentale de l'effet des chicanes sur les capteurs solaires plans à air, par simulation de l'énergie solaire", $3^{\text {èmes }}$ Journées Maghrébines sur la Mécanique, Institut de Mécanique, Guelma (Algérie), VI, (29-30 avril 1997), pp 212-218.

[13] Le Ray M., Deroyon J.P., Deroyon M.J., Minair C., " Critères angulaires de stabilité d'un tourbillon hélicoïdal ou d'un couple de tourbillons rectilignes, rôle des Angles Privilégiés dans l'optimisation des ailes, voiles, coques des avions et navires", Communication à l'Association Technique Maritime et Aérodynamique, Bulletin de l'ATMA, Paris, (avril 1985), pp 511-529.

[14] Messaoudi H.,"Structures tourbillonnaires induites par des obstacles triangulaires complexes et interactions ailes delta minces-corps de révolution. Application des Angles Privilégiés, en Aérodynamique et Energétique", thèse doct, Valenciennes, (1996).

[15] Abene A., "Etude systématique des positions et de la stabilité des structures tourbillonnaires au-dessus d'ailes ogivales et de cônes", thèse doctorat, Valenciennes, (1990).
[16] Letz T., "Modélisation et dimensionnement économique d'un système de chauffage domestique biénergie", thèse doct, INSA Lyon, (1985).

[17] Lewis W.K., "The rate of drying of solid materials", Journal of. Ind and Eng. Chem, Vol 13, 5, (1921), pp 427-432.

[18] Sherwood T.K., "The drying of solid", V 21, 10, (1929), pp $12-16$.

[19] Kondé G., "Résolution des équations de Luikov appliquée au séchage de l'oignon en vu de la réalisation de séchoirs solaires dans les pays sahéliens", thèse doct, Perpignan,(1983).

[20] Pasumarthi N., Sherif S.A., "Experimental and theoritical performance of a demonstration solar chimney model-part II : Experimental and theorical results \& economic analysis", Internat Journal Of Energy Research, 22, (1998), pp 443-461;

[21] Desmons J.Y., "Formulation et résolution numérique des problèmes aux limites appliquées, aux générateurs de chaleur tubulaires enterrés", thèse doctorat, Valenciennes, (1984).

[22] Benyounes R., "Prévision numérique et expérimentale de la réponse intrinsèque d'un échangeur bitubulaire enterré en régime continu", thèse doctorat, Valenciennes, (1993).

[23] Portales B., "Etude et expérimentation du chauffage solaire des serres à stockage thermique souterrain", thèse doctorat, Valenciennes, (1984).

[24] N'Dongo M.M., "Etude théorique d'un générateur solaire à air chaud constitué d'une serre agricole et d'un stockage de chaleur en sous-sol à l'aide de conduits. Application au séchage", thèse doctorat, Clermont-Ferrand II. Blaise Pascal, (1989).

[25] Dubois V., " Etude détaillée des structures tourbillonnaires développées à l'extrados de corps élancés simples, complexes et de corps de révolution. ", thèse doctorat, Valenciennes, (2005).

[26] Abene A., Dubois V., Michel Le Ray M., A. Ouagued A., "Study of a solar air flat plate collector: use of obstacles and application for the drying of grape", Journal of food engineering $65,(2004)$.

[27] Abene A., Dubois V., Michel Le Ray M., Ouagued A., « Etude expérimentale des performances thermiques de diverses configurations de chicanes placées dans la veine d'écoulement », Les Technologies Avancées n 16, Alger, (2003).

[28] Abene A., Dubois V., Michel Le Ray M., Si-Youcef M., Ouagued A., «Etude expérimentale de capteurs solaires à air : le séchage de la figue » Les Technologies Avancées n ${ }^{\circ} 17$, Alger, (2005).

[29] A. ABENE "Visualisation of Vortex Structures Developed on the Upper Surface of Double-Delta Wings", J Aeronaut Aerospace Eng 2:118, doi: 10.4172/2168-9792.1000118. September 2013

[30] A. ABENE An experimental study of the drying of papayes by solar panels -journal of sustainable development studies, ISSN 2201-4268 volume 7,number 1,2014,84-108 octobre2014

[31] A. ABENE An vortex structures on the upper surface of a pointed gothic wing observed at low ,median and high incidences -journal of vortex science and technology,ISSN 2090-8369 volume2-1, janvier 2015. 